\title{
Enterochromaffin Cell
}

National Cancer Institute

\section{Source}

National Cancer Institute. Enterochromaffin Cell. NCI Thesaurus. Code C12575.

The most abundant and widely distributed type of enteroendocrine cell found in the gastrointestinal tract. It is characterized by serotonin production and an affinity to binding silver and chromium salts. 